\title{
COMPARATIVE STUDY OF POST ISLAMISM BETWEEN PARTAI KEADILAN SEJAHTERA (PKS) WITH ADALET VE KALKINMA PARTISI (AKP)
}

\author{
Gili Argenti \\ Fakultas Ilmu Sosial dan Ilmu Politik \\ Universitas Singaperbangsa Karawang \\ E-mail: gili.argenti@fisip.unsika.ac.id
}

\begin{abstract}
After the Arab Spring, political Islam was initially expected to contribute significantly to political development and democracy. In fact, it is far from expectations. The Islamist group failed to adapt to the democratic system, the conflict with the long-lasting secular group finally invited the military to intervene. While in other parts of the world two Muslim-majority countries, Indonesia and Turkey, political Islam can adapt to the values of western democracy. This paper is a comparative study of political parties that compare post Islamism between PKS (Indonesia) and AKP (Turkey). Two political parties that successfully adapt to liberalism. There are two dimensions of post Islamism compared. First, a comparison of pragmatic steps that PKS and AKP make when facing a complex political reality. Second, the comparison of non-ideological strategies pursued by PKS and AKP, when facing national elections. In this research used descriptive qualitative method through the literature data, that is data arranged in the form of documents related to the problem under investigation. Like books, newspapers, articles, and journals. Based on this research can be known that the step of political pragmatism conducted by PKS and AKP is a rational choice, when there is a shift in voter behavior of Indonesia and when facing Kemalist secularist group in Turkey. The non-ideological strategy is carried out by PKS and AKP by campaigning on substantive issues, not discouraging the establishment of an Islamic state (shariah formalism) with a focus on issues related to economic welfare and integration to the EU.
\end{abstract}

Key words: Adalet Ve Kalkinma Partisi, Democracy, Partai Keadilan Sejahtera, Post Islamism.

\section{STUDI PERBANDINGAN POST ISLAMISME ANTARA PARTAI KEADILAN SEJAHTERA (PKS) DENGAN ADALET VE KALKINMA PARTISI (AKP)}

\begin{abstract}
ABSTRAK
Pasca musim semi demokrasi di Timur Tengah, Islam politik yang awalnya diharapkan memberikan kontribusi besar terhadap pembangunan politik dan demokrasi. Pada kenyataanya jauh dari harapan. Kelompok Islamis gagal melakukan adaptasi dengan sistem demokrasi, konflik dengan kelompok sekuler yang berkepanjangan akhirnya mengundang militer melakukan intervensi. Sedangkan dibelahan dunia lain dua negara mayoritas berpenduduk muslim, yaitu Indonesia dan Turki, Islam politik mampu beradaptasi dengan nilai-nilai demokrasi barat. Tulisan ini merupakan studi perbandingan partai politik yang membandingkan post Islamisme antara PKS (Indonesia) dengan AKP (Turki). Dua partai politik yang berhasil beradaptasi dengan liberalisme. Terdapat dua dimensi post Islamisme dibandingkan. Pertama, perbandingan langkah pragmatisme yang dilakukan PKS dan AKP ketika menghadapi realistas politik yang heterogen. Kedua, perbandingan strategi non-ideologis yang ditempuh PKS dan AKP, ketika menghadapi pemilihan umum nasional. Penulis menggunakan metode deskriptif kualitatif dalam penelitian ini dengan menggunakan data literatur, yaitu data yang tersusun dalam bentuk dokumen-dokumen yang berkaitan dengan permasalahan yang sedang diteliti. Seperti buku, koran, artikel dan jurnal.Kesimpulan dari penelitian ini Langkah pragmatisme politik yang dilakukan PKS dan AKP merupakan sebuah pilihan rasional, ketika terjadi pergeseran perilaku pemilih Indonesia serta ketika menghadapi kelompok sekuleris Kemalis di Turki. Strategi non platfrom ideologis dilakukan PKS dan AKP dengan mengkampanyekan isu-isu bersifat subtansi, tidak mewacanakan pendirian negara Islam (formalisme syar'iat) dengan fokus mengusung isu-isu subtansi terkait kesejahteraan ekonomi dan integrasi ke Uni Eropa.
\end{abstract}

Kata kunci: Adalet Ve Kalkinma Partisi, demokrasi, Partai Keadilan Sejahtera, Post Islamisme. 


\section{INTRODUCTION}

Research on post Islamism has been done by several researchers, including research on post-Islamism AKP Turkey (Dzakirin, 2012). This research explains the political pragmatism of AKP against secular-Kemalist groups since 2002. Then post-Islamism study in Iran and Egypt (Bayat, 2011). This research demonstrates the emergence of a new generation of political Islam in both countries, a generation different from previous political Islam, a generation very open to democratic values from the west. Subsequent research on political Islam in Malaysia on post-Islamism PAS (Mutalib and Zakaria, 2015). This research explains the accommodation of PAS on the values of freedom, openness, and democracy.

This research is a comparative study of post Islamism between two political parties in a non-Middle Eastern Islamic state between Indonesia (Partai Keadilan Sejahtera/PKS) and Turkey (Adalet Ve Kalkinma Partisi/AKP). This research would like to clarify that post Islamism between PKS and AKP is indicated by scolding the step of political pragmatism and non-ideological platform.

After the collapse of the New Order, the phenomenon of political Islam become an interesting theory. The party system in Indonesia used a multi-party system, from dozens of political parties from 1999 to 2014. The outline of political parties could be grouped into two major groups, the Nationalist Party and the Islamic Party. One of the phenomenal Islamic parties in the reform era is the PKS, a political party that is identical with these urban Muslims, formerly called the Partai Keadilan (PK). In the 1999 election Partai Keadilan in the House of Representatives (DPR RI) only get seven legislative seats, of course, this result does not meet the electoral threshold so that the Partai Keadilan is not eligible to become the election participants in 2004. Unless renamed and the symbol of the party, finally on 20 April 2002 declared the PKS as a new party which is the efficacy of PK struggle (Al Hamdi, 2013: 100).

PKS based on Islam, with the aim of building a just and prosperous Islamic based civil society within the framework of NKRI. Civil society is a society of high and advanced civilization which is based on values, norms, laws, morals supported by faith, plurality, being open and democratic, and working together to safeguard the sovereignty of the state (Qodir, 2013:149). Although the foundation of Islamic PKS in its vision, mission and its Articles of Association does not mention will establish an Islamic state. Although for PKS, Islamic relations and the state can not be separated. The establishment of an Islamic state is another matter. According to Hidayat Nurwahid, former President of PKS 2001-2004 said the Islamic state is not something that takes precedence, which is more mainstream how the values of Islam is present in the rules of public life. The country desired PKS is a nation of justice and prosperity (Furkon, 2004:232-234).

The Islamic world is currently shocked by the phenomenon of the AKP in Turkey that has repeatedly won elections in the secular state. The AKP party is a party founded by Turkish Islamists. Although it was founded with the spirit of Islamic revival, it was designed as an open and modern party. Even the AKP accepted secularism values with new interpretations. Secularism according to AKP is understood not negation (religious) which the French state practiced by rejecting religion both in political strata and in individual expression. (Dzakirin, 2012:76-77). The discourse of Post Islamism is one proof that there has been a shift in the orientation of political Islam in both countries, the Islamic solution they offer is no longer symbolic-ideological, but sub-pragmaticdimensional.

Based on the above background, the central question that became the focus in this paper are what is the step of political pragmatism conducted by the post-Islamism group in Indonesia (PKS) and in Turkey (AKP) when facing a complex political reality? And what is the ideological non-platform strategy of the post-Islamism group in Indonesia (PKS) and in Turkey (AKP) when facing elections? To dissect the object of this study, the author uses an analytical theory of post Islamism. According to Bayat (2011:98), Post Islamism is characterized by a series of social and intellectual movements mobilized by youth, students, women and religious intellectuals, by compromising faith with freedom, religion and human rights, or transcending Islamic rule by requiring freedom of individual choice, pluralism, and religious ethics. Post Islamism is different from Islamism which tends to impose an Islamic state, Post 
Islamism still rejects secularism against religion, but it also denies the theocracy. According to Post Islamism is not anti-Islam, but not secular, even highly upholds faith, but also appreciates the freedom of its citizens. Post Islamism is a political aspiration of religious society in a democratic country.

According to Fahmi (2016), Post Islamism is the latest trend that arose in the global political Islam movement, its emergence in line with the demands to fulfill the will of democracy. Before the rise of Post Islamism, he argued that the Islamic political movement adopted the ideology of Islamism or the political movement that wanted to form a government with holistic Islamic interpretation. Post-Islamism was a new strategy of political Islam to be able to carry out its existence, by changing the movement strategy of idealism the Islamic state to a more realistic-pragmatic Islamic political idea. The Post Islamist group declared itself that ideology is no longer necessary, for them the practice of the autocratic government does not provide many benefits to the economic, social and civic systems of the state. There needs to be a different step in implementing the government with the creation of the latest social space that fits the culture of the community. For Post Islamism, the production of this new social space can be stimulated by the political Islam movement by making high regard for justice, democracy, and human rights.

\section{METHOD}

The author uses a qualitative descriptive method in this study, a method of analyzing data shown or presented not in the form of statistics, but in the way of depiction a political phenomenon that occurs. The authors in this study using data literature, the data are arranged in the form of documents relating to the problems under investigation. Like books, newspapers, articles, and journals. To process the data obtained, the author uses several stages. First, in collecting this data, the researcher uses data collection technique with library study, that is collecting data from the literature by reviewing its contents through books, notes, and documents. Second, test and analyze the data critically, with this criticism is expected to get validity of data source used in research. Third, connecting one event to another, so it becomes a whole political sequence.

\section{DISCUSSION}

\section{History of Adalet Ve Kalkinma Partisi (AKP)}

According to Chalik (2017:132-133), given the categorization of countries in the Islamic world today, according to him there are three categories of main trends of Islamic countries, namely Islamic, Muslim and secular countries. The Islamic state tends to make Islam a way of life and the legal basis of the state; then the Muslim countries is a Muslim country that does not directly cause Islam the base of the state. Finally, a secular state that strictly separates state affairs from religion.

This Turkish secularism is part of Kemal Attaturk's plan to bring Turkey closer to the western world, for him the Turks should become utterly western in all aspects of life. The Kemalist government, for the last time, issued a ban on the use of clothes that are considered religious clothing in public places, including forbidding the wearing of headscarves for Muslim women in government and educational institutions. The secularization of Kemal Ataturk has the Westward principle or the inclination of the western world. The world of the west is not only crucial in political affairs but also in economics. The importance of the western world in the eyes of Mustafa Kemal Ataturk can be seen from the principles and goals developed by it. The principles and objectives built by Mustafa Kemal Ataturk make Turkey more focused on establishing political, economic and military cooperation with western countries. (Taradewi, Wiranata, \& Parameswari, 2015).

The birth of the AKP in the national political stage of Turkey cannot be separated from the military coup case against the victory of the Welfare Party (Refah Partisi) in 1997. Partai Refah was founded by Muslim scholar Necmettin Erbakan in 1981, supported by scholars, scientists, industrialists and Turkish society. Necmettin Erbakan indeed could not be released as a symbol of Islamism in Turkey at that time; he was the founder of the National Movement of View (Milli Gorus Hareketi) in 1960. The Milli Gorus group has many of the same characteristics as other Islamist movements in the world, continually linking the decline of the Islamic world due to the lack of commitment of Muslims to their religion, and not to make Islam a guide for living in a state. They also view Islam as an ideology as well as 
a basis for making changes in the community as a whole. The supporters of the Gorus Gorus group come from students, traders and the pious middle class who have not been represented by secular parties (Bubalo,2012:73-74).

The presence of Milli Gorus on the Turkish political scene that gave birth to the Refah Party, began when the closing of madrassas and religious schools in Turkey in 1924 by the secular regime. This incident resulted in many young Turks going to Egypt to study religious education, especially religious education at AlAzhar University after they graduated, they later re-took the role of "Transmitter" political Islam movement in Turkey. During their college in Egypt, these Turkish students came into contact with the Muslim Brotherhood (IM) thinking; it is no wonder that in the $1960 \mathrm{~s}$, the work of translations of the original IM authors was widely published in Turkey. For example, the work of Hasan Al-Banna began to be translated and published, also the interpretation of Sayyid Qutb and it can not be denied that the works of Al-Banna and Qutb significantly affect the young generation who became supporters and members of Milli Görüs Harekati. Erbakan emerged as an important channel of the Muslim Brotherhood to Turkey. Erbakan is deeply inspired by the writings of Sayyid Qutb, especially the writings of Qutb's call for rural education to regulate itself and gradually gain control of government from the urban elite (Qureta.com, 1 September 2017).

In 1995 the Refah Party became the winner of the national elections, thus delivering Necmettin Erbakan to the Turkish Prime Minister when he became prime minister of Turkey, Erbakan sought to develop good relations with Arab countries, so that the economic welfare of the Arab countries could be improved in the middle of Turkish society. Also, the Turkish government seeks to implement a multi-dimensional political approach with the neighboring countries. His foreign policy view has two pillars, close cooperative relationships, and unity among Islamic countries. The step of integration among Islamic countries is manifested by establishing the Eight Developing D-8 aimed at forming a strong economic and political union, with members of Turkey, Iran, Malaysia, Indonesia, Egypt, Bangladesh, Pakistan and Nigeria (Soekanto, 2016:32).
Seeing the politics of Erbakan which is considered to have an Islamic agenda, the military along with secular groups pressed Erbakan to withdraw from his office, even the Refah Party through the court was frozen by the Constitutional Court, as it was considered to promote fundamentalist Islam in Turkey. Before being frozen, on November 23, 1997, Erbakan read out a defense speech on the allegations of the military, rejecting claims that the Refah Party abandoned the constitution of a secular state and wanted to turn Turkey into an Islamic state. This Erbakan defense does not have much effect (Soekanto, 2016:32).

Following the dissolution of the Refah Party in January 1998, then supporters of political Islam in Turkey took the initiative to establish a new party, the Party of Goodness ). There is an exciting feature of the birth of the Party of Goodness; its presence was accompanied by the presence of two essential factions within the party body, between the reformist faction (yenilikciler) and the traditional faction (gelenekciler). The reformist group emphasized the importance of new regeneration in party leadership, among its leaders including Abdullah Gul, Melih Gokcek, and Recep Tayyip Erdogan. But the faction is marginalized, as the traditional group led by Recai Kutan dominates the party stewardship. But the Age of the Good Party did not last long, on 22 June 2001, the party was dissolved by the government on charges of endangering Turkey's secular ideology. After the Party of Goodness was disbanded by the Turkish political Islam groups experiencing divisions, the traditional faction established the Happiness Party (Saadet Partisi), while the reformist wing established the AKP under the leadership of Erdogan (Alfian, 2015:64-65).

The emergence of the AKP on the Turkish political scene did not happen suddenly, the presence of a new face of political Islam was preceded by the presence of reformist groups within the Party of Good. When the Goodwill Party (fazilet partisi) held a national convention, Abdullah Gul, one of the leaders of the reformist faction, ran for the post of chairman. In his campaign to gain the number one position in the Good Kind Party, Gul delivered some pragmatic political platforms such as avoiding conflict with the secular military, Western-oriented foreign policy, meaning to pass on Turkish loyalty to NATO and re-join the EU effort. Through this 
political platform Gul wanted to distinguish himself from Erbakan, he pursued pro-Western political diplomacy. Although in the convention Gul lost votes with his rival. (Bubalo, 2012:8081).

After the defeat of the party convention, Abdullah Gul and the reformist group prepared for the establishment of a new political party for one year, on August 14, 2001, the Justice and Development Party or Adalet Ve Kalkinma Partisi (AKP) was formed. The AKP symbol is a bright bulb that represents the continuity of light. Then Recep Tayyip Erdogan was appointed the leader of the party in hopes of his image and reputation as a successful former mayor in Istanbul will be a symbol and a political appeal (Dzakirin, 2012:34-35).

According to Erdogan, his party is not a religious party but a party that keeps togetherness. He explains that the AKP does not exploit religious issues for political ambition to gain power. For him, the AKP party follows a clear political direction to achieve the political objectives that Attaruk has proclaimed, establishing a modern, cultured society in Islam. The AKP Party identified itself as a conservative democrat party. This conservative term does not have to be associated with a political party that has an agenda to distance itself from progressive policies. Conservatives interpreted by the AKP are nothing more than an attempt to obey religious, spiritual values, but with respect for a change. This means that the AKP ideology is in the right spectrum position, on the expectation of social welfare improvement and economic growth which then combine it with moral, traditional and religiosity order (Amin, 2014: 150-151).

\section{Political Pragmatism of AKP}

For sixteen years the AKP managed to establish its political power in Turkey, recorded some of the successes that the party has achieved. In its first year of control, the AKP managed to raise three times the income per capita of the Turks, which was initially 3,000 to 13,000 US dollars. This success is undoubtedly inseparable from the economic program designed by Erdogan, the Turkish economy which previously relied more on the agricultural sector, it changed to the industrial and service sectors. The result can be seen from the number of visits of foreign tourists who previously four million trips to thirty-five million visits per year. (Soekanto, 2016).

Erdogan and AKP are well aware that to improve the Turkish economy is necessarily political, pragmatic measures. First, regarding the role of the military, Erdogan pursued a policy of bringing Turkey closer to the EU and the North Atlantic Treaty Organization (NATO). Because the primary requirement to be a member of both organizations, the country must be democratic, and there is no military intervention in any political affairs. Second, to eradicate corruption, at the beginning of his reign, Erdogan was very hard on himself and his party on corruption, he did not hesitate to punish people in his party if he was involved in fraud. As a result, the Erdogan government is known to be very clean and has succeeded in cutting down the long bureaucratic lines of the previous government's legacy. Third, the tribal Kurds of the AKP government recognize the rights of this tribe by giving the opportunity to use their language and culture in the public sphere, especially Erdogan managed to guarantee the political representation of the Kurds in parliament (Harian Umum Republika, 15 June 2015).

In the field of international political relations of the Turkish government under the AKP, it pursues a pragmatic political strategy by establishing communication with all parties and alienating Turkey from confrontation with other countries. Ahmat Davutoglu, one of the AKP officials who once served as Foreign Minister and Prime Minister of Turkey, explains Turkey's foreign policy to adopt a policy of "zero matters with neighboring countries." Zero policy issues need to be taken by Turkey because the country's position and geography are in Europe, Asia, the Balkans, the Caucasus and the Middle East. A situation that makes Turkey a transit zone between regions (Harian Umum Republika, 9 January 2017).

According to Alfian, he describes some of the political pragmatism policies adopted by the AKP during the ruling, among others (1) The AKP's political program in the economic field dramatically emphasizes liberal economy, foreign investment, privatization and regulation of open market economies. But despite the proliberalization of the economy, the AKP continues to agree on the state budget for social services. It means that the Turkish economic program strongly supports the open market system or 
capitalism, while still providing subsidies for the poor. (2) In the field of democratization, the AKP strongly emphasizes the consolidation of democracy, through reforms related to human rights, and is involved in the strengthening of civil society. (3) The religious field and moral values of the AKP emphasize secular order; moral values are left to norms that develop in society, rather than Islamic values. Religious freedom is part of the democratic system. (4) The AKP places great emphasis on decentralization and capacity building of local government policymaking. (5) Foreign policy, the AKP has a political orientation to the west, with a commitment to fight for Turkey as a member of the European Union. In addition to being open and compromising in solving a variety of crucial issues, including the case of Cyprus. (6) The political style of the AKP emphasizes the process of dialogue and the pursuit of consensus and tends to position itself as a center-right party (Alfian, 2015: 85-86).

\section{Non-Ideological Platform Strategy of AKP}

Erdogan asserted that the AKP is a conservative party of Democrats, so the AKP has a more rational, empirical and pragmatic view. Conservative ideologies are more pragmatic rather than ideological, conservative AKPs are reflected in public policies such as being strictly opposed to immoral acts in society, but permissive to private freedom such as easing taxes for large entrepreneurs and limiting the role of the state on economic and investment issues (Alfian, 2015: 111).

Aside from being a center-right party, the political policies of AKP and Erdogan are considered to reflect the different faces of political Islam from Islamism, i.e., First, Erdogan, although an Islamist group, he is the leader who firmly makes secularism the constitution or state ideology. It was delivered in many places. Second, Erdogan continues to open diplomatic ties with Israel. Even Erdogan has just normalized his relationship with Israel. We know that Islamists can not have relations with Israel. This non-ideological choice of Islamist AKP, because in an objective political map in Turkey, Kemalism or secularism is a fixed price. When Islamist groups try to harass or interfere with Kemalism or secularism, then they are immediately coupled by the military. Such is the experience of previous coup history in Turkey.

\section{History of Partai Keadilan Sejahtera (PKS)}

Entering the year 1990, it can be said that almost all the major campuses show the intensity of Islam is very high. The increase of Islamism as a whole can be seen from the many uses of hijab by female students, full of Islamic study program at Kampus Mosque, the use of Arabic language in daily student interaction and others. The spirit of these students certainly cannot be separated from the active role of Campus Dakwah Institution (Lembaga Dakwah Kampus/LDK) which consistently convey Islamic preaching among students. At the same time, in the early 1990s, the opposition to the New Order regime increased in the number of students, including da'wah activists. On the surface of this LDK activist resistance spirit is slow and tend to be gentle, not frontal and provocative like their other colleagues. LDK activists continue to build oppositional cultures with different faces. They build organized agreements with LDKs on various campuses to wage a golput action in the 1997 elections, using the doctrine of embers, which teaches the total dissolution of all things perceived to be contrary to Islamic values. (Najib,2001:63-65).

The appearance of Partai Keadilan (PK) dated July 20, 1998, and declared on 9 August 1998 in Jakarta, signifies the presence of these da'wah activists to the public. Symbolizing two golden crescent moon and the straight line between the two crescent moon, the PK affirms its identity as a party based on Islam. (Damanik, 2002:244-245). In the 1999 election Justice Party in the House of Representatives only get seven legislative seats, of course, this result does not meet the electoral threshold so that the Partai Keadilan is not eligible to become the election participants in 2004. Unless renamed and the symbol of the party, finally on 20 April 2002 declared the PKS as a new party which is the efficacy of PK struggle (Al Hamdi, 2013:100).

While the attitude of PKS to democracy according to Fahri Hamzah (2010:198), that Islam is synonymous with the principle of democracy in it. The universal idea of democracy in line with the universal concept of Islam. Democracy is the best means to roll out the ideals of Islamic society. So it is proper that democracy is considered to be used as an Islamic goal. In addition to moderating the idea of democracy, the moderate attitude of the PKS seems to be shown by the presence of 
PKS members from non-Muslim circles. Even among the members of the legislature, there are about 20 non-Muslim PKS legislators in Papua and NTT electoral districts. According to Hilmi Aminuddin (Harian Republika, Chairman of the Majelis Syuro PKS-Hilmi Aminuddin - We Want To Build Togetherness And Diversity. Date 22 June 2010). The reason PKS gives nonMuslim membership space, because in areas where the number of non-Muslim population is the majority. PKS is often visited by people who want to be PKS member. Even though it has been explained PKS as Islamist party, but they do not mind being PKS member. They enter into PKS not because their religion is different, but looking at the political programs that PKS offers that they value as the solution to the problems they face. Moreover, in the Second National Conference of PKS which lasted from 17-20 June 2010, this da'wah party declared itself as an open party.

\section{Political Pragmatism of PKS}

Political parties in Indonesia are difficult to remove from the struggle between Islamist and nationalist groups, the polarization of identity politics usually refers to the classical study of Clifford Geertz. But the question is whether flow politics is still relevant to explain the current dynamics of Islamic politics. The study of William Liddle and Saiful Mujani concludes that the flow politics has faded. Liddle and Mujani's thesis is based on the results of a nationwide survey in 1999 that explains PDI Perjuangan voters $(63 \%)$ in the 1999 election comes from the santri. It's mean that Muslim voters have shifted political choices that no longer choose because of its identity as a Muslim (Muhtadi, Prospek Partai Islam Dalam Pemilu. Koran Sindo, 25 Oktober 2008).

The results of research William Liddle and Saiful Mujani strengthened the opinion of Islamic political experts from the State University of Jakarta (UIN) Syarif Hidayatullah Jakarta, Prof. Azyumardi Azra. According to him, Indonesia's voters are increasingly rational and independent, consequently ideological and ideological considerations in choosing no longer dominant. Azyumardi assessed after the fall of President Suharto regime there is a trend of political struggle that tends toward the opportunist rather than ideological. Even the development of Indonesia post-1990 increasingly leads to the waning of political flow. This is due to sociological changes in Indonesia due to increased education and economic mobility (Republika, 17 Maret 2014).

Shifting voter behavior becomes a challenge for Islamic parties in Indonesia especially PKS. Anis Matta's remarks in the second session of PKS in Jakarta, which stated that the PKS would revise its party's constitution to open up non-Muslim spaces, is a big step taken by PKS. This PKS attitude had brought the PKS more central in the ideological spectrum, even when the 2004 election of this party tried a pragmatic strategy by imaging itself as a party that put forward universal values, a cleaner and more caring image offered to Indonesian voters than from Islamic symbols. The choice of electoral tactics proved successful with the skyrocketing PKS votes reaching 7.3 million or $8.33 \%$. Likewise in the 2009 Election, PKS increasingly intensified the campaign as an open party, the PKS advertises by selling Sukarno, KH. Ahmad Dahlan, KH. Hasyim Asy'ari and Muhammad Natsir. The message to be conveyed wants to target the nationalist group, Muhammadiyah, NU, and Masyumi. (Koran Suara Merdeka, 18 June 2010).

At Mukernas in Bali in early 2008, the PKS even declared itself as an open party, although initially there were rumors of fierce internal party resistance, through the Thought Forum (Multaqo Fikri) for two days in October 2008. The internal resistance was not confirmed, ideas or ideas how it is communicated not to substance. Openness to the PKS is not merely an electoral strategy to enlarge a party market niche, but transparency is considered part of an Islamic character, the PKS believes in an open and moderate view of Islam. And the party that makes Islam as its ideology must have two characters of moderation and openness (Muhtadi, 2012: xxiii).

The attitude of openness and political pragmatism of PKS is demonstrated by recruiting members from people with nontarbiyah backgrounds (LDK activists). Even in the 2004 election, PKS's party attracted more than 30 non-Muslim legislative candidates. Also, the PKS also recruits non-Muslims as members. It is evident from the dismissal of the DPD of the Piniai Partai Keadilan on June 5, 2002, with the majority of its administrators being Christian. PKS leaders also provide 
an opportunity for Hindu religious leaders to become members of the legislature (Basyir, 2014).

In the 2004 elections, the PKS also reduced the issues of being Islamic, even seemingly avoiding showing the overly flashy behavior of Islami. This party campaigns for clean and caring slogans and reinforces secular topics such as the fight against corruption, good governance, and socio-economic equity. In fact, in the implementation of the National Working Congress (Mukernas) of PKS in Bali on 1-3 February 2008, some media covering the event described the disappearance of the usual takbir screams echoed in PKS events. In fact, the thunder is the applause of participants who are sometimes followed by shouting "Merdeka." Change of PKS appearance, as part of pluralism campaign carried by PKS (Muhtadi, 2012: 33).

The attitude of Islamic party ideology openness and political pragmatism, especially $\mathrm{PKS}$, is something realistic. According to Bima Arya, that Islamic parties to improve electoral performance is very determined its ability in reconstructing itself amidst the psychic reality of this nation. The Islamic party should put forward the real agendas directly in touch with the public interest rather than carrying ideological discourses such as Islamic Shari'ah formalism; the Islamic party has no choice but to move on particular issues such as welfare, law enforcement, and anti-corruption. (Sugiarto, 2010:12).

\section{Non-Ideological Platform Strategy of PKS}

In achieving their objectives, political parties need long-term and medium-term strategies, as well as the MCC. First, strategies related to mobilizing and mobilizing the masses in the formation of the public opinion or during the election period. This strategy is essential to win votes that support the victory of a political party. Second, the strategy of a political party to blend with other parties. Third, the approach of political parties in developing and empowering the political organization as a whole. These strategies are a means to achieve the stated goals (Aminulloh, 2010).

The PKS strategy to win the election is done in the following ways: First, PKS cadres come down, meaning that they go directly to the community to hear the aspirations, what is desired and complained by the community.
PKS strategy with listening is a means of party communication with direct door to door constituents. Second, the PKS invites cooperation with other parties including the nationalist party, because the PKS is not possible to handle all the problems and demands that exist in the community itself, the PKS invites people or parties who can be invited to work together to help solve the problems is in the community. Third, the PKS speaks to the community by the party platform as a follow-up of the PKS invites. Fourth, the winning of PKS, which means that from programs that have been done by PKS cadres in the middle of society, it is hoped the realization of community sympathy. This form of community sympathy is expected to help achieve the PKS target in winning the election.

The advantage of PKS compared to other Islamic parties, namely its ability in managing identity politics issues, although PKS as an Islamic party, he never campaigned for an Islamic state. PKS is more likely to explore the meaning of Islam by making substantial improvements, although the improvement phase of the ummah requires a process and takes a long and protracted time. Concrete evidence of the PKS attitude statement in 2000 most of the Islamic parties such as PPP and the UN raised the issue of the Jakarta Charter, but the PKS stance instead supported the Madinah Charter (Sandhi,2014).

\section{The Trajectory of Post Islamism: PKS and AKP}

In this study, the author compares two dimensions of Post Islamism between AKP and PKS. In the first dimension of the political pragmatism between AKP and PKS. According to the author, both the AKP or PKS are the two political parties belonging to the Islamic party category. Although AKP has a conservative ideology, historically the founder of the party originated from the Milli Görüs Harekati group of very Turkic Islamists influenced by the ideas of political Islam movement of Ikhawanul Muslimin from Egypt. However, the political situation in Turkey is not conducive for the Islamist party to present itself as the ideologicalidealist party. Because the dominant pro-secular (Kemalist) military domination is very strong, the shadow of the dissolution of Islamic parties and the government's Islamic coup d'etat 
appears before the eyes. The choice of AKP is appropriate by highlighting the steps of political pragmatism. Likewise with the PKS, despite the different conditions of political conditions with Turkey, Muslim voters in Indonesia from elections to elections experience a significant shift, they have a choosing orientation not based on religious equality aspect, but rather to the political solutions offered over the sharing of problems that occur in society. Comparison between PKS and AKP regarding Post Islamism can be explained in the following table 1 .

The AKP's pragmatic steps include identifying itself as a conservative or middleright conservative party, in common with western political parties (the Christian Democratic Union Party in Germany and the Republican Party in the United States). One of the characters of the conservative democratic party is that they have a supporter base from middle-class groups who have conservative religious ideas, but they have a perspective in favor of liberalism and democracy. The AKP Party has these characteristics. Namely, the AKP constituents derived from the middle-class pious who accept the principles of democracy as well as market liberalism as the ideal political-economic system. Furthermore, AKP's political program does not advocate for the establishment of Islamic law; the AKP emphasizes the Islamic substance aspect so that it is a high priority to realize the values of the universal goodness of Islam. Also, the AKP has succeeded in positioning the military as a defense force not to intervene or intervene in civilian politics. The AKP's success in removing the military in this politics, as AKP successfully approached the west, the Turkish government under Erdogan became the only government that consistently wanted to bring Turkey into the EU. While one of the conditions of Turkey can join the EU membership, requiring civil, political independence in running the government, which means eliminating the total role of military social-political in the national political stage.

In dealing with the Kurdish separatist movement, the AKP government pursued a dialogical path with the Kurds, a new way of Turkey's government to overcome the proindependence movement of the minority. Even under the Erdogan government, in addition to pursuing a dialogical strategy to resolve the conflict with the Kurds, a multiculturalism policy was also adopted, giving Kurdish cultural identity a chance to fill the public spaces in Turkey. This AKP approach is very different from previous Turkish government policies that use a militaristic-repressive approach; the Erdogan government wants to prove that the dialogue-culture way can be more effectively pursued in solving the separatist movement. Finally, the pragmatism of the AKP is

Tabel 1. Comparison of post islamism between PKS and AKP

\begin{tabular}{|c|c|c|}
\hline $\begin{array}{c}\text { POST } \\
\text { ISLAMISME }\end{array}$ & Partai Keadilan Sejahtera (PKS) & Adalet Ve Kalkinma Partisi (AKP) \\
\hline \multirow[t]{3}{*}{$\begin{array}{l}\text { Political } \\
\text { Pragmatism }\end{array}$} & $\begin{array}{l}\text { 1. Identify himself as a conservative } \\
\text { democratic or center-right party. }\end{array}$ & 1. Identify as moderate Islamic party. \\
\hline & 2. Not struggling to form an Islamic state. & $\begin{array}{l}\text { 2. Not struggling to form an Islamic } \\
\text { state }\end{array}$ \\
\hline & $\begin{array}{l}\text { 3. Emphasizing aspects of the substance of } \\
\text { Islam, so as to regard the main priority } \\
\text { is to be a clean government and good } \\
\text { governance }\end{array}$ & $\begin{array}{l}\text { 3. Emphasizing the value of Islam is } \\
\text { present in the rules of public life, the } \\
\text { country that is desired PKS is a state of } \\
\text { justice and prosperity }\end{array}$ \\
\hline \multirow[t]{2}{*}{$\begin{array}{l}\text { Non Ideological } \\
\text { Platform Strategy }\end{array}$} & $\begin{array}{l}\text { 1. Campaigning the issue of substance that } \\
\text { becomes the solution of socio-economic } \\
\text { problems in society. }\end{array}$ & $\begin{array}{l}\text { 1. Campaigning Substance Issues by } \\
\text { finding solutions to various problems }\end{array}$ \\
\hline & $\begin{array}{l}\text { 2. Using a highly structured network of } \\
\text { organizations, a nationwide network of } \\
\text { organizations throughout Turkey, such as } \\
\text { the Women Branch and Youth Branch }\end{array}$ & $\begin{array}{l}\text { 2. Make the cadre the spearhead of the } \\
\text { realization of party programs. }\end{array}$ \\
\hline
\end{tabular}


demonstrated by offering a different political platform with Islamists; the AKP encourages the involvement of Turkish women to participate in political life, the steps taken by the AKP include the mobilization and empowerment of women political cadres in the AKP.

While PKS pragmatic politics conducted among others, since the establishment of this party which was initially called the Partai Keadilan (PK) in its Articles of Association and Bylaws are not listed about the establishment of an Islamic state or the implementation of Islamic Shari'ah. Because according to the PKS, the Islamic state is not something that is prioritized, more importantly how the Islamic values are present in the public life rules, the country that is desired PKS is a just and prosperous country. Even at the beginning of the reform when there was a debate about the proposed amendment of Article 29 of the 1945 Constitution, the Partai Keadilan did not suggest a return to the Jakarta Charter but offered a universal discussion of the Medina Charter as well as respecting the plurality of nationalities. While looking at the democratic system, the PKS considers that Islam is synonymous with the principle of democracy, the universal idea of democracy in line with the universal concept of Islam, according to the PKS democratic system is the best means to roll the ideals of Islamic society. In addition to moderate democracy, PKS also receives membership from non-Muslim, even there are about 20 non-Muslim members of parliament (DPRD) in the electoral district of Papua and NTT. At the National Working Congress (Mukernas) in Bali early 2008, PKS even declared itself as an open party. This attitude of political pragmatism which is shown by PKS, as a strategic step of PKS to add support base from other community apart from PKS traditional voters.

The Ideological Non-Platform Strategy, the AKP also presented a major belief about the new politics in Turkey, by campaigning on substantive issues to be solved by the socio-economic problems of Turkish society, such as restructuring the financial sector and eliminating private sector growth barriers. This factor ultimately makes the AKP always win the election from time to time; this is what makes the AKP survive. Also, organizational factors have also played a major role in the AKP's victory since the 2002 elections. The structure of the AKP organization network is highly structured and even has extraordinary organizational power. A nationwide network of organizations throughout Turkey, including the Women Branch and Youth Branch, two-party wing organizations a significant role in the AKP victory. The real power of the AKP lies in its highly organized organizational structure management, the image as one of the modern parties visible here so that the party structures can become effective party machines in accumulating the political support of the Turkish people. Even the AKP has a 24-hour community complaint center, meaning the AKP always does political work at all times, regardless of election performance, the AKP always responds when handling complaints from the public. Similarly, PKS that makes the cadre as the spearhead of the realization of party programs, through the network of Jama'ah Tarbiyah PKS able to maximize the political work in the field. Party wings in the form of CSOs, NGOs or Lembaga Dakwah are consistently present in the midst of society, to jointly seek solutions from various problems. The PKS does not sell the issues of enforcing Islamic Shari'ah to the Indonesian people as an electoral magnet. But campaigning on clean and professional government, the last PKS uses various media as a party propaganda tool, so that the political message of PKS can be distributed equally to society.

\section{CONCLUSION}

The step of political pragmatism by PKS is a rational choice when there is a shift in Indonesian voter behavior from voter orientation to the equation to problem-solving orientation. The political pragmatism is done by AKP due to the failure of Turkish Islamists during the time of facing Kemalist secularist group through military intervention. Often the victory of the Islamic party is not recognized, even the government's coup in the middle of the road.

The non-ideological strategy was conducted by PKS by campaigning on substantive issues, not discouraging the establishment of an Islamic state (shariah formalism). Then make the cadre as the spearhead of victory and the use of media. The AKP identifies itself not as an Islamist party, but a conservative democratic party (center right). AKP's campaign strategy focuses on substantive issues related to 
economic welfare and integration of Turkey to the European Union. The last AKP victory from elections to the election is also supported by a proper organizational structure of the AKP, especially the wings of the youth AKP.

\section{REFERENCES}

Aiqani, N. (2017). Erdogan, AKP dan Ikhwanul Muslimin. Retrieved September 1, 2017, from https://www.qureta.com/post/ erdogan-akp-dan-ikhwanul-muslimin

Al Hamdi, R. (2013). Partai Politik Islam Teori Dan Praktik Di Indonesia. Yogyakarta: Graha Ilmu.

Alfian, M.A. (2015). Militer dan Politik Turki: Pergeseran Politik dan Terpinggirnya Militer Pasca AKP. Bekasi: Penerbit PT Penjuru Ilmu Sejati.

Amin, M. (2014). Pengaruh Adalet Ve Kalkinma Partisi (AKP) Dalam Trasformasi Peta Politik Di Turki. Jurnal In Right: Jurnal Agama dan Hak Azazi Manusia, Vol. 4 (1).

Bayat, A. (2011). Pos-Islamisme. Yogyakarta: LKiS.

Bayat, A. (2011). The Post-Islamist Revolutions What the Revolts in the Arab World Mean . Retrieved August 3, 2017, from https://www.foreignaffairs. com/articles/north-africa/2011-04-26/ post-islamist-revolutions

Basyir, A. (2014). Ideologi Politik Dilematis Partai Keadilan Sejahtera (PKS) Antara Gerakan Tarbiyah dan Pragmatisme. IN RIGHT Jurnal Agama dan Hak Azazi Manusia, Vol. 3, No. 2, Mei 2014.

Bubalo, A. (2012) PKS dan Kembarannya: Bergiat jadi Demokrat di Indonesia, Mesir dan Turki. Jakarta: Komunitas Bambu.

Chalik, A. (2017). Islam, Negara dan Masa Depan Ideologi Politik. Yogyakarta: Pustaka Pelajar.

Damanik, A. (2002). Fenomena Partai Keadilan: Transformasi20Tahun Gerakan Tarbiyah Di Indonesia. Bandung: Teraju.

Dzakirin, A. (2012). Kebangkitan Post-Islamisme: Analisis Strategi AKP Turki Memenangkan Pemilu. Solo: Era Intermedia.
Evanuar, G.S. (2014). Post-Islamisme dan Disorientasi Gerakan Islam. Retrieved January 31, 2017, from https:// bringbackthevictory.wordpress. com/2014/01/03/post-islamisme-dandisorientasi-gerakan-islam/

Fahmi, W.A. (2004). Pemikiran Pasca Islamisme Dalam Konteks Gerakan Islam di Malasyia. UMRAN-International Journal of Islamic and Civilizational Studies Furkon, A.M. (2004). Partai Keadilan Sejahtera: Ideologi dan Praksis Politik Kaum Muda Muslim Kontemporer. Jakarta: Teraju.

Hamzah, F. (2010). Negara, Pasar dan Rakyat: Pencarian Makna, Relevansi dan Tujuan. Jakarta : Faham Indonesia.

Maarif, A. (2016). Erdogan Vs Gulen: Bencana Politik Bagi Turki Bagian II. Harian Umum Republika.

Mashuri, I. (2015). Ketika Rakyat Turki "Menegur" Tuan Erdogan. Harian Umum Republika.

Mashuri, I. (2017). Kedigdayaan Turki Erdogani Sedang Diuji Para Teroris. Harian Umum Republika, Tanggal 9 January 2017.

Muhtadi, B. (2010). PKS Menjadi Partai Terbuka, Sukseskan. Koran Suara Merdeka

Muhtadi, B. (2012). Dilema PKS: Suara Dan Syariah. Jakarta: KPG.

Mutalib, M. dan Zakaria, W. (2015). PascaIslamisme dalam PAS: Analisis Terhadap Kesan Tahalluf Siyasi. International Journal of Islamic Thought, Vol. 8: Dec. 2015.

Pizaro, M. (2016). Balada Erdogan dan Gulen. Harian Republika.

(2010, June 22). Ketua Majelis Syuro PKS-Hilmi Aminuddin-Kami Ingin Membangun Kebersamaan Dan Keragaman. Harian Republika.

(2014, March 17). Pemilih Muslim Semakin Independen. Harian Republika

Qodir, Z. (2013). HTI Dan PKS Menuai Kritik: Perilaku Gerakan Islam Politik Indonesia. Yogyakarta: JKSG. 
Rifki, A. (2016). Zuhairi Misrawi: Kudeta Turki Bukan Pertarungan Islam-isme versus Sekularisme. Retrieved September 25, 2017, from http://www.madinaonline. $\mathrm{id} /$ sosok/wawancara/zuhairi-misrawikudeta-turki-bukan-pertarunganislamisme-versus-sekularisme/

Soekanto, S. (2016). Strategi Pemenangan Pemilu AKP di Turki dan PKS di Indonesia Studi Perbandingan. Depok: Universitas Indonesia Press.

Sugiarto, B. A., \& Heryadi, E. (2010). Anti partai. Depok: Gramata Publishing.

Sandhi,W.R.(2014).Skripsi:PolitikIdentitasPartai Islam (Studi Partai Keadilan Sejahtera). Retrieved August 2, 2017, from http:// jurnal.umrah.ac.id/wp-content/uploads/ gravity forms/1-c61c9cb232a03a 96d0947c6478e525e/2014/08/JURNALWIRA.pdf

Taradewi, D. (2015). Analisis Perubahan Kebijakan Luar Negeri Turki Terhadap Tiongkok pada Masa Pemerintahan Adalet Ve Kalkinma Partisi (AKP) Tahun 2002-2013. Jurnal Hubungan Internasional, Vol 1 No 03, 2015.

TRT. (2016). Wawancara Erdoğan dengan TRT. Retrieved August 12, 2017, from http:// www.trt.net.tr/melayu/turki/2016/08/05/ wawancara-erdogan-dengan-trt-545357

Zulfahmi. (2014). Fethullah Gulen: Sang Inspirator Gerakan Damai Masyarakat Sipil di Turki. Jakarta: Penerbit Universitas Indonesia Press. 